\title{
MENGELOLA HUBUNGAN DENGAN PELANGGAN PADA PRAKTIK PEMASARAN BUSINESS TO BUSINESS (B2B) DENGAN ORIENTASI PENCIPTAAN LOYALITAS
}

\author{
Audita Nuvriasari \\ Fakultas Ekonomi Universitas Mercu Buana Yogyakarta \\ email: audy_nuvriasari@ymail.com
}

\begin{abstract}
The relationship between organization and their customers is a critical issue when establishing a long-term relationship. It is not only in Business to Customer (B2C) relationship but also in Business to Business (B2B). To maintenance the long-term relationship, the organization must create a customer loyalty in the business. The importance and benefits of attracting and maintaining loyal customers has arisen because there is a general acceptance that profitability follows customer loyalty. The objective of this research is to increase the understanding of managing and maintaining the relationship between customer and supplier in B2B marketing. Furthermore, the result of this research is to give some recommendations to create a customer loyalty in B2B marketing practice. Qualitative analysis is used in this research since it is the appropriate method to meet our purpose. In order to accomplish this research, one company in mattress industry (PT. Dinamika Indonusa Prima) has been used as an object. Some indicators to evaluate the practice of $B 2 B$ marketing are: purpose of exchange, nature of communication, managerial intent, managerial focus, managerial investment, and managerial level. The result of this study indicate that the practice of B2B Marketing has done in a good practice and organization must meet the customer need in order to maintain customers and create a customer's loyalty.
\end{abstract}

Keywords: Business to Business (B2B) marketing, maintaining customer, customer's loyalty

\section{PENDAHULUAN}

Keberhasilan perusahaan salah satunya diciptakan melalui keberhasilan kuantitas penjualan produk pada pasar masal, asumsinya semakin produktif suatu perusahaan maka keuntungan atau manfaat akan menyertainya. Kondisi semacam ini harus diimbangi dengan upaya perusahaan untuk mengelola hubungan baik dengan pelanggan sehingga akan tercipta kepuasan dan loyalitas. Secara umum kepuasan akan memberikan dampak yang positif pada terciptanya loyalitas pelanggan. Loyalitas pelanggan yang meningkat menyebabkan profitabilitas yang lebih tinggi, retensi pegawai yang lebih tinggi dan basis keuangan yang lebih stabil (Griffin, 2003).

Saat ini pasar telah mengalami banyak perubahan dimana konsumen memiliki lebih banyak pilihan dan posisi tawar tawar yang kuat. Sehingga apabila perusahaan tidak memperharikan kebutuhan dan keinginan konsumen maka konsumen akan dengan mudah beralih pada produk lain. Hal ini tidak hanya terjadi pada pasar Business to Customer (B2C) akan tetapi juga terjadi pada pasar Business to Business (B2B).

Business to Business (B2B) Marketing merupakan sistem pemasaran dari satu perusahaan kepada perusahaan lain yang cukup unik dan tidak menggunakan teknik atau cara pemasaran seperti yang biasa diketahui oleh pasar. Dimana pada pemasaran Business to Business (B2B) lingkupnya terbatas dan tidak untuk seluruh kalangan. Hanya dibutuhkan beberapa orang saja untuk memutuskan pembelian ataupun penjualan antar perusahaan. Business to Business (B2B) merupakan kegiatan per- 
usahaan yang menjual barang dan jasa bisnis yang menghadapi pembeli profesional yang terlatih dan banyak tahu, terampil dalam menilai tawaran yang bersaing (Kotler dan Keller, 2009).

Dalam merancang strategi pemasaran pada Business to Business (B2B) maka perlu dilakukan pergeseran pemikiran dari mindset pelanggan ke mindset bisnis, yakni bisnis yang efektif dan efisien. Strategi pemasaran pada Business to Customer (B2C) secara umum lebih mefokuskan pada manfaat dan keputusan pembelian tidak hanya berdasarkan pada fungsi saja melainkan juga dipengaruhi oleh nilai emosional. Berbeda pada Business to Business (B2B), pasar bisnis tidak akan melakukan pembelian karena nilai emosional tetapi lebih cenderung bersifat rasional. Pelanggan Business to Business (B2B) lebih memperhatikan komponen harga dan kualitas serta fungsi yang ditawarkan oleh suatu produk. Selain nilai fungsional. Di samping itu pelanggan bisnis juga memfokuskan pada efisiensi sehingga perlu diperhatikan manfaat penghematan yang ditawarkan oleh penyedia produk. Penghematan tersebut dapat dalam bentuk biaya, waktu maupun sumber daya.

Pengelolaan Business to Business (B2B) secara prinsip berbeda dengan Business to Customer (B2C) meskipun dari sisi market size lebih sempit tetapi bukan berarti lebih mudah dalam pengelolaannya. Hubungan pelanggan bisnis dan pemasok lebih dekat dibandingkan pada pasar konsumen dan secara geografis pembelinya lebih terkonsentrasi (Kotler, 2009). Dari sisi konsumen Business to Business (B2B) memiliki kompleksitas dalam hal pengambilan keputusan dimana banyak pihak internal customer yang secara langsung maupun tidak langsung terlibat dalam pengambilan keputusan sehingga pemasar harus mampu mengidentifikasi siapa saja yang menempati posisi tersebut dan kemudian berusaha menjalin relationship yang efektif. Menjaga hubungan antara perusahaan dengan konsumen merupakan hal penting yang harus dilakukan untuk membina dan mempertahankan hubungan jangka panjang sehingga dapat tercipta keunggulan kompetitif yang berkesinambungan (Sustainable Competitive Advantage).

Berdasarkan hasil dari sejumlah penelitian pada konteks pemasaran Business to Business (B2B) dijelaskan bahwa loyalitas merupakan hasil dari kepuasan secara ekonomis dari mitra bisnis yang bersumber dari volume, margin dan potongan harga khusus. Kepuasan akan berhubungan positif dengan tingkat kebertahanan konsumen, hal ini mengindikasikan bahwa hubungan jangka panjang dengan mitra bisnis tercipta karena adanya kepuasan terhadap kinerja perusahaan (Rauyruen, Miller dan Barret, 2007).

Dalam penelitian ini indikator dalam pengkajian praktik Business to Business (B2B) dikembangkan dan didaptasi dari hasil penelitian pada Journal of Marketing oleh Coviello, Brodie, Danaher dan Johnston (2002) dalam Tjiptono, Chandara, Diana (2004) . Dimana kajian terhadap praktik Business to Business (B2B) meliputi: (1) tujuan pertukaran, (2). Karakteristik komunikasi, (3). Sasaran manajerial, (4). Fokus manajerial, (5). Investasi manajerial, dan (6). Jenjang manajerial. Pengkajian tidak hanya dilakukan pada praktik pemsaan Business to Business (B2B) saja akan tetapi juga menggali rekomendasi strategi yang dapat diimplementasikan oleh perusahaan guna terciptnya hubungan (relationship) yang baik dengan pelanggan di pasar bisnis sehingga dapat tercipta kepuasan dan loyalitas pelanggan.

\section{KAJIAN PUSTAKA}

Penelitian yang dilakukan oleh Tonton dan Gyamfi (2006) mengenai "Maintaining Customer Relationship in Business To Business Marketing" menjelaskan tentang hubungan supplier dengan pelanggan dalam pengelolaan dan pemeliharaan hubungan tersebut. Penelitian ini meng- 
gunakan pendekatan analisis kualitatif dengan penghimpunan data primer melalui wawancara secara terstruktur dengan 2 (dua) perusahaan berskala internasional yang bergerak dibidang logistik dan industri mekanik. Narasumber wawancara adalah manajer penjualan dan staf pemasaran pada kedua perusahaan tersebut. Berdasarkan hasil penelitian dapat disimpulkan bahwa agar perusahaan dapat mengelola dan memelihara hubungan yang baik dengan pelanggan maka perlu disususn perencanaan startegis dimana harus didukung dengan adanya kemampuan dan kinerja perusahaan yang baik. Perusahaan tidak hanya mendasarkan pada hubungan transaksional akan tetapi lebih menempatkan pelanggan sebagai faktor kunci dengan membina hubungan relasional. Apabila perusahaan meunjukkan kinerja yang buruk maka tidak akan tercipta kepuasan dan loyalitas pelanggan dan sebaliknya apabila perusahaan berhasil menunjukkan kinerja yang baik maka akan mampu menciptakan kepuasan dan loyalitas pelanggan. Disamping itu untuk menciptakan kepuasan dan loyalitas pelanggan perlu adanya koordinasi, kemitraan dan komunikasi yang bersifat intensif dengan pelanggan. Pada dasarnya loyalitas tidak bersifat statis tetapi sangat tergantung pada kinerja perusahaan seperti: kualitas produk yang ditawarkan, ketepatan waktu penghantaran, layanan pendukung yang diberikan dan lain-lain. Loyalitas dapat diciptakan dengan meningkatkan kualitas hubungan dengan pelanggan serta perlu mengembangkan program-program loyalitas.

Penelitian yang dilakukan oleh Henriksoon dan Wall (2009) mengenai "How To Create Customer Satisfaction: Customer Satisfaction in Business to Business Relationship" meneliti tentang faktor-faktor yang mempengaruhi penciptaan kepuasan pelanggan pada pemasaran B2B. Penelitian dilakukan pada industri mesin photocopy dan Teknologi Informasi dengan menggunakan pendekatan kualitatif model distribusi frekuensi dan nilai rata-rata. Berdasarkan hasil penelitian dapat dijelaskan bahwa faktor-faktor yang mempengaruhi kepuasan konsumen pada industry mesin photocopy dan Teknologi Informasi berdasarkan peringkatnya (ranking 1 sampai dengan 10) adalah sebagai berikut. 1) Kualitas produk. 2) Kemudahan penggunaan. 3) Dukungan teknis. 4) Harga. 5) Ketersediaan staf. 6) Perlakuan staf terhadap pelanggan. 7) Pemahaman tentang produk. 8). Waktu penghantaran. 9) Seleksi produk. 10) Penanganan tagihan.

Dalam penelitian tersebut dapat disimpulkan bahwa salah satu strategi untuk menciptakan kepuasan pelanggan adalah dengan menghantarkan kinerja perusahaan sesuai dengan apa yang diharapkan oleh pelanggan sehingga perlu dilakukan identifikasi terhadap kebutuhan dan keinginan pelanggan.

Penelitian yang dilakukan oleh Yee (2008) mengenai "Customer Perceived Quality, Relationship Quality and Business Loyalty: An Example of B2B Organization" antara lain meneliti tentang pengaruh CPQ (kualitas yang diterima pelanggan) terhadap $R Q$ (kualitas hubungan) dan pengarug RQ (kualitas hubungan) terhadap BL (loyalitas pelanggan bisnis). Dimensi pada Customer Perceived Quality meliputi: kualitas produk dan kualitas layanan, sedangkan dimensi Relationship Quality meliputi: kepuasan kemitraan, kepercayaan dan komitmen. Loyalitas pelanggan bisnis meliputi loyalitas yang bersifat aktif dan pasif. Berdasarkan hasil penelitian dapat disimpulkan bahwa terdapat pengaruh yang positif dan signifikan antara Customer Perceived Quality terhadap Relationship Quality baik secara parsial maupun simultan. Dimana semakin baik kualitas produk dan layanan yang diterima pelanggan maka semakin tinggi tingkat kualitas hubungan dengan pelanggan. Hasil penelitian selanjutnya adalah terdapat pengaruh yang positif dan signifikan antara Relationship Quality terhadap Business Loyalty. Dimana semakin baik kualitas hubungan (kepuasan kemi- 
traan, kepercayaan dan komitmen) maka aan semakin tinggi tingkat loyalitas pelanggan bisnis.

Penelitian tentang kepuasan dan loyalitas konsumen pada pasar bisnis juga dilakukan oleh Liao (2012) dengan topik "Service Quality and Customer Satisfaction: Direct and Indirect Effects in a B2B Customer Loyalty Framework". Penelitian dilakukan pada industri besi baja di Taiwan dengan tujuan penelitian untuk mengkaji lebih dalam hubungan antara kualitas layanan, kepuasan konsumen dan loyalitas konsumen pada konteks B2B. Berdasarkan hasil penelitian dapat disimpilkan bahwa kualitas pelayanan dan kepuasan konsumen pada pasar B2B secara langsung berhubungan atau mempengaruhi loyalitas konsumen. Sedangkan kualitas layanan secara tidak langsung mempengaruhi loyalitas konsumen dimana kepuasan konsumen sebagai variabel perantara. Kualitas pelayanan merupakan faktor yang paling signifikan mempengaruhi kepuasan konsumen pada imdustri besi baja.

Pengelolaan hubungan dengan pelanggan pada pasar B2B terkait dengan nilai pelanggan, kepuasan, loyalitas dan biaya peralihan dilakukan oleh Lam, Shankar dan Murthy (2009). Penelitian dilakukan pada kelompok industry jasa penghantaran yang bergerak dalam pasar global (DPS Company) dengan mitra bisnis adalah sub agen jasa penghantaran. Adapun hasil penelitian antara lain sebagai berikut. Nilai pelanggan memiliki pengaruh yang positif terhadap kepuasan konsumen, kepuasan konsumen memiliki pengaruh yang positif terhadap loyalitas konsumen, dan biaya peralihan memiliki pengaruh yang positif terhadap loyalitas konsumen. Dalam penelitian ini direkomendasikan bahwa dalam rangka meningkatkan kepuasan pada konsumen bisnis maka perlu berupaya untuk meningkatkan nilai yang diterima oleh konsumen dan meminimalkan faktor-faktor yang menurunkan kepuasan konsumen seperti ketidak terbukaan perusahaan dengan mitra bisnis.
KAJIAN TEORI Mengelola Hubungan Pelanggan B2B

Untuk memperbaiki efektivitas dan efisiensi maka rekanan dan pelanggan mengeksporasi cara yang berbeda-beda dalam mengelola hubungan bisnis mereka, anatar lain dengan cara melakukan koordinasi vertikal (Adisaputro, 2010). Koordinasi vertikal antara pembeli dan penjual diharapkan dapat meningkatkan hubungan antar mereka dan didukung dengan mengembangkan kepercayaan sehingga diharapkan terjadi hubungan jangka panjang yang sehat. Adapun manfaat dari hubungan ini adalah sebagai berikut. 1) Terjadi peningkatan bisnis yang lebih substansial antar kedua belah pihak. 2) Menghasilkan keuntungan yang lebih banyak bagi kedua belah pihak. 3) Mencegah jika salah satu pihak mengacaukan hubungan baik yang telah terjadi. 4) Mencegah jika salah satu pihak menjadi lebih mampu mengendalikan pihak lain. 5) Kedua belah pihak akan memetik manfaat terjadinya economics of scale.

\section{Loyalitas Pelanggan Pada B2B}

Loyalitas pelanggan dalam konteks pemasaran $B 2 B$ adalah komitmen untuk membeli produk/jasa secara konsisten dalam waktu kedepan, baik merek maupun cara pembeliannya dan berpengaruh secara situasi serta merupakan usaha pemasaran yang dimiliki secara potensial dalam pertukaran dan perilaku. Loyalitas pelanggan menunjukkan perilaku pembelian yang berlangsung secara kontinyu terhadap produk atau jasa perusahaan, dimana evaluasinya dapat ditunjukkan melalui perilaku konsumen, intensitas pembelian ulang, dan rekomendasi positif dari mulut ke mulut (Liao, 2012)

Loyalitas pelanggan dipahami sebagai pembelian nonrandom (pembelian yang bersifat tidak acak dan tindakan pembelian terjadi tidak kurang dari dua kali) yang diungkapkan dari waktu ke waktu oleh beberapa unit pengambilan 
keputusan (Griffin, 2003). Dua kondisi penting yang berhubungan dengan loyalitas termasuk dalam koteks pasar bisnis adalah retensi pelanggan (customer retention) dan total pangsa pelanggan (total share of customer). Idealnya perilaku pembelian dari pelanggan yang loyal mencermikan kedua kondisi tersebut. Loyalitas pelanggan yang meningkat menyebabkan profitabilitas yang lebih tinggi, retensi pegawai yang lebih tinggi dan basis keuangan yang lebih stabil.

Dalam mengadopsi programprogram loyalitas, fokus utama perusahaan bukanlah untuk menarik konsumen baru, melainkan untuk mendapatkan loyalitas dari para konsumen yang sudah ada atau pelanggan, dan pada akhirnya untuk meningkatkan hubungan pelanggan dan penyedia layanan (Zeithaml dan Bitner, 2000). Upaya untuk mengelola dan memelihara hubungan dengan pelanggan agar dapat tercipta kepuasan dan loyalitas, antara lain dapat dilakukan dengan cara (Adisaputro, 2010): 1) Meningkatkan manfaat financial bagi pelanggan yang membeli lebih sering atau lebih banyak dengan memberikan insentif moneter. 2) Membentuk program keanggotaan sehingga dapat diperoleh informasi pasar yang memadahi tentang situasi bisnis. 3) Menambah manfaat social dengan cara menciptakan hubungan yang lebih personal antar anggota dengan perusahaan. 4) Memperkuat hubungan struktural, misalnya menciptakan kontrak penjualan jangka panjang, harga lebih rendah untuk pembelian dengan kuantitas yang lebih besar dan menambah atau menyediakan jasa pelayanan jangka panjang sebagai tambahan terhadap pembelian produk perusahaan.

\section{METODOLOGI PENELITIAN}

Penelitian diakukan pada perusahaan yang bergerak pada industri kasur pegas PT. Dinamika Indonusa Prima Cabang Yogyakarta yang bertidak selaku supplier dan distributor kasur pegas merk Airland dan asesoris keperluan tidur kepada mitra bisnis seperti: toko mebel, jasa penginapan, instansi pemerintah dan swasta.

Subyek penelitian adalah pimpinan dan karyawan yang terlibat langsung dalam kegiatan pemasaran yang terdiri dari manajer regional (1 orang), supervisor (1 orang) dan staf pemasaran (3 orang). Data penelitian berupa data primer dengan menggunakan instrumen pengumpul data kuesioner dan wawancara terstruktur dengan pimpinan perusahaan untuk menggali informasi strategi yang telah diimplementasikan dalam mengelola hubungan dengan pelanggan.

Adapun dimensi yang digunakan untuk pengkajian praktik B2B mengadopsi dari penelitian yang dilakukan oleh Coviello, Brodie, Danaher dan Johnston (2002) dalam Tjiptono, Chandara, Diana (2004) dengan 6 (enam) dimensi pokok yang terdiri dari: (1) tujuan perrtukaran, (2). Karakteristik komunikasi, (3). Sasaran manajerial, (4). Fokus manajerial, (5). Investasi manajerial, dan (6). Jenjang manajerial. Pengukuran skala menggunakan skala Likert berjenjang 5 yakni: Tidak Pernah (score 1), Jarang (score 2), KadangKadang (score 3), Sering (score 4) dan Selalu (score 5). Metode penelitian menggunakan deskriptif (kualitatif) dengan alat mean arithmetic yang kemudian dikategorikan atas penilaian rentang skala (Budiyuwono, 2010).

\section{HASIL ANALISIS DAN PEMBAHASAN Deskripsi Praktik Pemasaran Business to Business (B2B)}

\section{Dimensi Tujuan Pertukaran}

Tujuan pertukaran mendeskripsikan fokus perusahaan dalam berinteraksi dengan pasar baik dalam hal tujuan memeroleh laba, mendapatkan informasi dari pelanggan maupun tujuan untuk membina hubungan jangka panjang dengan pelanggan. Adapun tujuan pertukaran pada PT. Dinamika Indonusa Prima Cabang Yogyakarta dapat dijelaskan sebagai berikut. 
Tabel 1: Tujuan Pertukaran - Interaksi Perusahaan dengan Pasar

\begin{tabular}{|c|c|c|c|}
\hline No & Dimensi Tujuan Pertukaran & Mean & Kategori \\
\hline 1. & $\begin{array}{l}\text { Meraih laba atau ukuran financial kinerja } \\
\text { lainnya }\end{array}$ & 4,80 & $\begin{array}{c}\text { Selalu menjadi tujuan } \\
\text { pertukaran }\end{array}$ \\
\hline 2. & Mendapatkan informasi pelanggan & 4,00 & $\begin{array}{l}\text { Sering menjadi tujuan } \\
\text { pertukaran }\end{array}$ \\
\hline 3. & $\begin{array}{l}\text { Membina hubungan jangka panjang dengan } \\
\text { pelanggan }\end{array}$ & 4,80 & $\begin{array}{l}\text { Selalu menjadi tujuan } \\
\text { pertukaran }\end{array}$ \\
\hline
\end{tabular}

Sumber: Data Primer yang diolah

Berdasarkan Tabel 1 dapat dijelaskan bahwa fokus perusahaan dalam berinteraksi dengan pasar orientasi utamanya adalah untuk meraih laba dan membina hubungan jangka panjang dengan pelanggan. Mengingat tujuan untuk memperoleh laba atau kinerja financial lainnya menjadi salah satu orientasi perusahaan, maka PT. Dinamika Indonusa Prima Cabang Yogyakarta menetapkan target penjualan minimal setiap bulannya yakni 600 unit per bulan atau 3600 unit per semester. Penetapan target ini diperlukan untuk menjaga keberlangsungan pertumbuhan perusahaan. Secara rata-rata setiap bulan realisasi penjualan selalu melebihi target penjualan sehingga perusahaan dapat meraih laba. Sebagai ilustrasi pada tahun 2010 semester I realisasi penjualan sebesar 6069 unit dan pada semester II sebesar 6365 unit.

Orientasi utama lainnya adalah membina hubungan jangka panjang dengan pelanggan, hal ini ditujukan agar tercipta kepuasan dan loyalitas pelanggan sehingga akan memberikan dampak positif bagi perusahaan. Sejumlah program pembinaan hubungan jangka panjang yang telah dilakukan antara lain: 1) Mengcover seluruh biaya promosi pemasaran produk dimana biaya iklan ini tidak dibebankan kepada mitra bisnis (toko-toko sebagai mitra) tetapi ditanggung sepenuhnya oleh PT. Dinamika Indonusa Prima Cabang Yogyakarta. Kegiatan promosi yang dilakukan antara lain advertising yang rutin dilakukan setiap bulannya $(10$ kali penayangan) melalui media cetak seperti: Kedaulatan Rakyat, Tribun Jogja, Harian
Jogja dan lain-lain. Dimana kegiatan ini sebagai salah satu bentuk penghargaan yang diberikan oleh perusahaan kepada mitra bisnis yang dapat mencapai target yang telah ditentukan. Selain iklan, kegiatan promosi lainnya yang ditanggung oleh PT. Dinamika Indonusa Prima Cabang Yogyakarta adalah pameran dan pemasangan billboard di toko-toko selaku mitra bisnis. 2) Penambahan insentif berupa tambahan diskon maupun special gift bagi toko maupun SPG. 3) Memberikan bonus-bonus khusus kepada mitra bisnis yang secara kontinyu berhasil melebihi target penjualan yang telah ditentukan, seperti: program liburan ke luar negeri.

Interaksi perusahaan dengan pasar guna memperoleh informasi pasar juga sering menjadi tujuan pertukaran perusahaan. Pencarian informasi pasar dilakukan oleh supervisor dan tim khusus pemasaran (team sales) dengan kegiatan tersebut antara lain berupa: 1) Kunjungan lapangan secara langsung kepada pihak mitra bisnis untuk memantau perkembangan pasar. 2) Memantau aktivitas dan perkembangan pesaing. 3) Menghimpun masukan dan minat pasar terhadap produk-produk perusahaan yang diperoleh melalui kegiatan pameran.

\section{Dimensi Karakteristik Komunikasi}

Komunikasi pemasaran perusahaan dalam penelitian ini meliputi: cakupan komunikasi, sasaran komunikasi, interaksi dengan pelanggan dan kemitraan dengan organisasi atau institusi lain, dengan hasil sebagai berikut. 
Tabel 2: Karakteristik Komunikasi

\begin{tabular}{llcc}
\hline No & Dimensi Karakteristik Komunikasi & Mean & Kategori \\
\hline 1. & Perusahaan berkomunikasi dengan pasar masal & 4,00 & $\begin{array}{c}\text { Sering menjadi orientasi } \\
\text { komunikasi }\end{array}$ \\
2. & $\begin{array}{l}\text { Perusahaan memiliki segmen khusus yang } \\
\text { disasar }\end{array}$ & 4,20 & $\begin{array}{c}\text { Sering menjadi orientasi } \\
\text { komunikasi }\end{array}$ \\
3. $\quad \begin{array}{l}\text { SDM khususnya di bagian pemasaran secara } \\
\text { intensif berinteraksi dengan pelanggan }\end{array}$ & 4,20 & $\begin{array}{c}\text { Sering menjadi orientasi } \\
\text { komunikasi }\end{array}$ \\
4. $\quad \begin{array}{l}\text { Adanya kemitraan atau jalinan kerjasama } \\
\text { dengan organisasi/institusi lain }\end{array}$ & 4,00 & $\begin{array}{c}\text { Sering menjadi orientasi } \\
\text { komunikasi }\end{array}$ \\
\hline
\end{tabular}

Sumber: Data Primer yang diolah

Komunikasi pemasaran pada PT. Dinamika Indonusa Prima Yogyakarta dengan pasar masal dilakukan melalui sejumlah kegiatan seperti: periklanan dan pameran. Kegiatan periklanan antara lain dilakukan secara rutin setiap bulan melalui media cetak lokal seperti: Kedaulatan Rakyat, Tribun Jogja, Merapi dan Radar Jogja. Kegiatan pameran secara umum dilakukan di pusat-pusat perbelanjaan seperti: Malioboro Mall, Ambarukmo Plaza Mall dan Progo. Informasi kegiatan pameran selain melalui media surat kabar juga bekerjasama dengan media radio seperti: Geronimo, Swaragama, GCD, dan lain-lain (Marantika, 2012).

Perusahaan memiliki segmen khusus yang menjadi sasaran dalam komunikasi pemasarannya yakni tokotoko yang menjadi mitra bisnis. Kegiatan periklanan maupun pameran yang dilakukan oleh perusahaan merupakan bentuk fasilitas yang diberikan kepada mitra bisnis dimana seluruh biaya ditanggung oleh perusahaan. Segmen khusus perusahaan bukanlah end user (konsumen akhir) akan tetapi adalah konsumen bisnis seperti: toko, perhotelan, balai diklat yang dikelola oleh instansi pemerintah maupun swasta.

Dalam menjalankan komunikasi pemasaran menugaskan tim khusus yakni Team Sales yang berinteraksi secara intensif dengan pelanggan. Kegiatan yang dilakukan antara lain adalah: melakukan kunjungan pada mitra bisnis, menghimpun informasi pasar dan pesaing, memberikan training kepada SPG toko selaku mitra bisnis, memberikan penjelasan produk secara langsung kepada SPG toko maupun pengunjung pameran.

Program jalinan kemitraan dengan pihak lain selaku partner bisnis juga dilakukan guna memperluas jaringan bisnis dan mempertahankan pelanggan yang sudah ada. Bentuk kemitraan antara lain dilakukan melalui kegiatan komunikasi pemasaran baik dalam bentuk iklan maupun pameran serta memberikan sejumlah fasilitas tambahan lainnya sperti penyediaan billboard, spanduk, brosur, flayer dan tools promosi lainnya serta beragam insentif seperti bonus, discount dan lain-lain. Disampig itu juga memberikan fasilitas training product knowladge bagi mitra bisnis. Mitra bisnis secara mayoritas adalah tokotoko di wilayah DIY seperti: Sami Agung Galeri, Adil Jaya, Griya Indah Mebel, Berdikari Mebel, Contempo, Asram, Sumber Abadi, Margo Murah, Sami Agung, Makmur Jaya dan lain-lain (Marantika, 2012).

\section{Dimensi Sasaran Manajerial}

Sasaran manajerial mendeskripsikan aktivitas pemasaran perusahaan yang ditujukan untuk sejumlah tujuan yang meliputi: upaya menarik pelanggan baru, mempertahankan pelanggan yang sudah ada, menjalin hubungan dengan pelanggan lain dan marketing coordination dengan sejumlah pihak. Berdasarkan hasil penelitian dapat dirangkum pada tabel berikut. 
Tabel 3: Sasaran Manajerial

\begin{tabular}{|c|c|c|c|}
\hline No & Dimensi Sasaran Manajerial & Mean & Kategori \\
\hline 1. & Menarik pelanggan baru & 4,80 & $\begin{array}{l}\text { Selalu menjadi sasaran } \\
\text { manajerial }\end{array}$ \\
\hline 2. & Mempertahankan pelanggan yang sudah ada & 5,00 & $\begin{array}{l}\text { Selalu menjadi sasaran } \\
\text { manajerial }\end{array}$ \\
\hline 3. & Menjalin hubungan kerjasama dengan pelanggan lain & 4,80 & $\begin{array}{l}\text { Selalu menjadi sasaran } \\
\text { manajerial }\end{array}$ \\
\hline 4. & $\begin{array}{l}\text { Mengkoordinasikan aktivitas antara perusahaan dengan } \\
\text { pihak lain seperti: distributor dan konsumen non personal }\end{array}$ & 4,60 & $\begin{array}{l}\text { Selalu menjadi sasaran } \\
\text { manajerial }\end{array}$ \\
\hline
\end{tabular}

Sumber: Data Primer yang diolah

Beradasarkan Tabel 3 dapat dijelaskan bahwa perusahaan selalu berorientasi pada upaya menarik pelanggan baru, mempertahankan pelanggan yang sudah ada, menjalin hubungan dengan pelanggan lain dan marketing coordination dengan sejumlah pihak. Hal tersebut ditujukan untuk memperluas pangsa pasar dan mempertahankan pasar yang telah diperoleh sehingga diharapkan dapat meningkatkan kinerja financial perusahaan.

Upaya menarik pelanggan baru dilakukan perusahaan dengan strategi market development dimana pelanggan tidak hanya terbatas pada toko-toko mebel tetapi juga diperluas pada segmen jasa penginapan, instansi pemerintah dan swasta khusunya untuk balai diklat dan rumah dinas. Sedangkan perluasan secara geografis dilakukan dengan memperluas area pemasaran tidak hanya di DIY tetapi juga di Jawa Tengah. Upaya mempertahankan pelanggan yang sudah ada dilakukan oleh PT. Dinamika Indonusa Prima Yogyakarta dengan strategi market penetration dimana perusahaan mendorong penjualan produk secara maksimal kepada pasar yang telah ada. Hal ini didukung dengan kegitan komunikasi pemasaran yang agresif.

Menjalin hubungan kerjasama dengan pelanggan dan koordinasi aktivitas pemasaran perusahaan dengan pihak mitra (sub agen) dilakukan oleh Team Sales PT. Dinamika Indonusa Prima Cabang Yogyakarta dibawah koordinasi supervisor dan manager area. Koordinasi dilakukan secara berkala dimana pihak perusahaan melakukan kunjungan secara langsung kepada mitra bisnis. Hal tersebut ditujukan untuk memepertahankan dan memelihara hubungan jangka panjang dengan pelanggan.

\section{Dimensi Fokus Manajerial}

Dalam melakukan perencanaan pemasaran perusahaan difokuskan pada sejumlah hal yang berhubungan dengan penawaran produk dan pelanggan. Adapun hasil penelitian terkait dengan fokus manajerial pada PT. Indonusa Prima Cabang Yogyakarta dapat dijelaskan sebagaimana tampak pada Tabel 4.

Fokus perencanaan pemasaran perusahaan utamanya adalah melakukan penawaran produk perusahaan yang dilakukan secara intensif untuk meingkatkan volume penjualan perusahaan. Penawaran produk yang bersifat masal dilakukan melalui kegiatan periklanan dan pameran sedangkan kegiatan penawaran yang ditujukan pada sub agen atau mitra bisnis dilakukan dengan personal selling.

Tabel 4: Fokus Manajerial Bidang Pemasaran

\begin{tabular}{llcl}
\hline No & Dimensi Fokus Manajerial & Mean & Kategori \\
\hline 1. & Penawaran produk perusahaan & 4,60 & Selalu menjadi fokus pemasaran \\
2. & Pelanggan pada pasar perusahaan & 3,80 & Selalu menjadi fokus pemasaran \\
\hline
\end{tabular}

Sumber: Data Primer yang diolah 
Perencanaan pemasaran perusahaan yang berorientasi pada pelanggan juga sering menjadi fokus perusahaan. Dimana pelanggan dalam hal ini adalah mitra bisnis atau sub agen (seperti tokotoko mebel) menjadi target pemasaran produk perusahaan. Keberadaan sub agen ini akan mempermudah jalur penyampaian produk kepada end-user. Perusahaan juga mendukung aktivitas pemasaran mitra bisnis baik dalam kegiatan komunikasi pemasaran, pemberian training product knowledge dan pemberian fasilitas-fasilitas promosi lainnya. Hal ini ditujukan agar pelanggan menjadi lebih loyal kepada perusahaan. Bagi pelanggan yang memiliki kinerja yang baik seperti dalam hal kinerja penjualan maka perusahaan akan memberikan kompensasikompensasi tertentu.

\section{Dimensi Investasi Manajerial}

Investasi manajerial mendeskripsikan sasaran investasi sumber daya pemasaran perusahaan yang mencakup sumber daya manusia, waktu dan finansial. Adapun sasaran investasi sumber daya pemasaran pada PT. Dinamika Indonusa Prima Cabang Yogyakarta dapat dijelaskan sebagai tampak pada Tabel 5 .

Sasaran Investasi manajerial khususnya investasi sumber daya pemasaran secara mayoritas berorientasi pada sasaran untuk mengembangkan relasi jaringan bisnis pada system pemasaran yang lebih luas. Hal ini dikarenakan perusahaan berkomitmen untuk mengembangkan perusahaan sejalan dengan misinya untuk menjadi pemipin pasar pada industri mebel khususnya kasur pegas. PT. Dinamika Indonusa Prima Cabang Yogyakarta mengembangkan relasi jaringan khususya bekerjasama dengan toko mebel selaku sub agen untuk penjualan kasur pegas. Saat ini upaya untuk mengembangkan jaringan bisnis tidak hanya sebatas dengan toko-toko mebel akan juga dikembangkan kerjasama dengan pihak perhotelan, wisama, balai diklat pemeritah dan rumah dinas. Selain itu cakupan wilayah juga tidak hanya sebatas di DIY tetapi juga bergerak di wilayah Karisidenan Solo, Karisidenan Kedu dan Karisidenan Banyumas.

Fokus investasi manajerial di bidang pemasaran yang mencakup bauran pemasaran (produk, harga, promosi dan distribusi), teknologi untuk memperbaiki komunikasi pemasaran dan membina hubungan secara personal dengan pelanggan juga sering menjdai sasaran majerial perusahaan.

Pada bauran pemasaran perusahaan berorientasi untuk menghasilkan produk yang berkualitas dengan infrastruktur yang memenuhi standar terbaik pada industry kasur pegas. Produk unggulan yang dihasilkan adalah kasur pegas dengan merek Airland dan sudah bersertifikasi ISO 9002. Selain produk kasur pegas juga memproduksi asesoris perlengkapan tidur seperti bantal dan guling.

Tabel 5: Sasaran Investasi Manajerial

\begin{tabular}{|c|c|c|c|}
\hline No & Dimensi Investasi Manajerial & Mean & Kategori \\
\hline 1. & Produk, promosi, harga dan aktivitas distribusi & 3,80 & $\begin{array}{l}\text { Sering sebagai sasaran } \\
\text { investasi manajerial }\end{array}$ \\
\hline 2. & $\begin{array}{l}\text { Teknologi untuk memperbaiki komunikasi dengan } \\
\text { pelanggan }\end{array}$ & 3,60 & $\begin{array}{l}\text { Sering sebagai sasaran } \\
\text { investasi manajerial }\end{array}$ \\
\hline 3. & $\begin{array}{l}\text { Meciptakan dan membina hubungan personal } \\
\text { dengan pelanggan }\end{array}$ & 3,80 & $\begin{array}{l}\text { Sering sebagai sasaran } \\
\text { investasi manajerial }\end{array}$ \\
\hline 4. & $\begin{array}{l}\text { Mengembangkan relasi jaringan bisnis pada system } \\
\text { pemasaran yang lebih luas }\end{array}$ & 4,20 & $\begin{array}{l}\text { Selalu sebagai sasaran } \\
\text { investasi manajerial }\end{array}$ \\
\hline
\end{tabular}

Sumber: Data Primer yang diolah 
Penetapan harga bersifat terstandarisasi mengacu pada harga yang ditetapkan oleh kantor pusat. Akan tetapi setiap cabang memiliki kebijakan tersendiri terkait dengan pemberian harga khusus kepada partner bisnis khususnya bagi partner bisnis yang mampu malampaui penjualan diatas target yang telah ditetapkan. Penetapan harga kepada mitra bisnis secara prinsip adalah seragam atau sama dan yang membedakan adalah program atau jenis kontrak apa yang diikuti oleh mitra bisnis sehingga akan mempengaruhi besaran discount yang diberikan. Harga khusus juga diberikan kepada mitra bisnis yang bersifat non kontrak seperti tender pengadaan atau adanya pengambilan dalam jumlah besar dalam satu waktu dan satu nota faktur.

Promosi sebagai alat untuk mengkomunikasikan secara pesuasif yang bersifat dua arah dari penyedia produk kepada konsumen. Kegiatan promosi yang digunakan berupa iklan dan pameran. Sasaran iklan dan pameran adalah sekelompok orang, perusahaan dan instansi yang dikategorikan mempunyai kepentingan terhadap produk. Media iklan yang digunakan adalah media cetak (surat kabar lokal) dan media elektronik (radio lokal). Sedangkan pameran dilakukan di pusatpusat perbelanjaan.

System distribusi produk dilakukan secara langsung oleh PT. Dinamika Indonusa Prima Cabang Yogyakarta yang ditangai khusus oleh Team Delivery dengan menghantarkan barang secara langsung kepada partner bisnis (seperti toko, hotel dan lain-lain) atau kepada konsumen akhir. Selain itu Team delivery juga membantu dalam pemasangan barang display baik di toko, pameran maupun di tempat penghantaran akhir konsumen.

Teknologi untuk memperbaiki komunikasi pemasaran dikembangkan tidak hanya bersifat konvensional melalui brosur, flayer, billboard dan sejenisnya akan tetapi juga memanfaatkan teknologi informasi yang berupa internet melalui web-site sehingga calon konsumen dapat beriteraksi secara langsung. Pemanfaatan teknologi informasi ditujukan untuk mempermudah dan mempercepat komunikasi pemasaran yang dilakukan.

Menciptakan hubungan secara personal dengan pelanggan terus dilakukan dengan cara melakukan kunjungan secara langsung pada mitra bisnis baik yang dilakukan oleh Team Sales, Supervisor maupun Area Manager. Kegiatan tersebut juga didukung dengan memberikan pelayanan sebaik-baiknya kepada partner bisnis sehingga tercipta kepuasan.

\section{Dimensi Jenjang Manajerial}

Jenjang manajerial menunjukkan pihakpihak dalam perusahaan yang menangani aktivitas pemasaran yang meliputi: tim khusus pemasaran, pimpinan perusahaan dan tim non-pemasar pada perusahaan yang bertanggungjawab atas pemasaran dan kegiatan bisnis lainnya, dengan hasil sebagai berikut.

Tabel 6: Jenjang Manajerial Yang Menangani Aktivitas Pemasaran

\begin{tabular}{llcc}
\hline No & \multicolumn{1}{c}{ Dimensi Jenjang Manajerial } & Mean & Kategori \\
\hline 1. & Tim khusus pemasaran & 4,80 & $\begin{array}{c}\text { Selalu menangani aktivitas } \\
\text { pemasaran }\end{array}$ \\
2. & Pimpinan Perusahaan atau Jajaran Pimpinan & 4,20 & $\begin{array}{c}\text { Selau menangani aktivitas } \\
\text { pemasaran }\end{array}$ \\
3. & $\begin{array}{l}\text { Non-pemasar yang bertanggungjawab atas pemasaran } \\
\text { dan aspek bisnis lainnya yang dimiliki oleh perusahaan }\end{array}$ & 2,80 & $\begin{array}{c}\text { Kadang-kadang menangani } \\
\text { aktivitas pemsaran }\end{array}$ \\
\hline
\end{tabular}

Sumber: Data Primer yang diolah 
Penangan aktivitas pemasaran pada PT. Dinamika Indonusa Prima Cabang Yogyakarta ditangani secara khusus oleh tim khusus pemasaran dalam hal ini adalah tim sales. Disamping itu penangan aktivitas pemasaran dan monitoring terhadap aktivitas tersebut dilakukan oleh jajaran pimpinan perusahaan yakni regional manager (kepala cabang) dan supervisor. Sedangkan SDM non-pemasar tidak bertanggungjawab secara langsung terhadap aktivitas pemasaran perusahaan. SDM non-pemasar bertanggungjawab terhadap tugas pokok dan fungsi masingmasing sesuai dengan bidang kerjanya, seperti: administrator, kepala gudang, sekretaris, tim delivery dan security.

Adapun penanganan aktivitas pemasaran oleh Tim Sales pada PT. Dinamika Indonusa Prima Cabang Yogyakarta, meliputi (Marantika, 2012): 1) Melakukan kunjungan berdasarkan area cover sesuai dengan klasifikasi kelas toko. 2) Melakukan active selling berkaitan dengan program insentif toko/SPG toko, training product knowledge kepada SPG toko, cek stok atau ketersediaan barang untuk mengisi stok toko maupun mengisi display. 3) Melakukan pengecekan terhadap barang-barang pendukung promosi (brosur, flayer, catalog, daftar harga, billboard dan lain-lain). 4) Melakukan pencatatan administrasi terkait dengan hasil kunjungan ke mitra bisnis, baik yang bersifat informasi competitor ataupun informasi penjualan. 5) Melakukan passive selling dengan mitra bisnis melalui programprogram sosial.

Sedangkan penangan aktivitas pemasaran dan monitoring dilakukan oleh kepala cabang dan supervisor, antara lain mencakup: 1) Menyusun perencanaan dan bertanggungjawab atas perencanaan, pelaksanaan serta pengawasan aktivitasaktivitas bisnis perusahaan termasuk aktivitas pemasaran agar sesuai dengan tujuan yang telah ditetapkan. 2) Memberikan laporan seluruh aktivitas bisnis perusahaan termasuk aktivitas pemasaran kepada general manager. 3) Menjalin hubungan kemitraan dengan pihak lain selaku calon konsumen maupun pelanggan tetap. 4) Melakukan kunjungan lapangan dengan pihak klien atau mitra bisnis sehingga dapat dilakukan monitoring terhadap perkembangan bisnis, permintaan produk dan informasi pasar. 5) Melakukan pengawasan pelaksanaan kegiatan yang berkaitan dengan pemasaran produk.

Berdasarkan hasil analisis deskriptif dapat dijelaskan bahwa perusahaan telah melaksanakan prkatik pemasaran Business to Business (B2B) dengan baik. Hal ini ditunjukkan dari orientasi praktik pemasaran yang lebih bersifat relational dengan berorientasi pada pelanggan baik pada aspek tujuan transaksi atau pertukaran perusahaan, orientasi komunikasi perusahaan, sasaran aktivitas pemasaran, fokus manajerial, investasi manajerial di bidang pemasaran dan penanggungjawab aktivitas pemasaran. Meskipun demikian masih diperlukan adanya upaya untuk memperbaiki efektifitas dan efisiensi dalam pengelolaan hubungan dengan mitra bisnis sehingga akan menghasilkan hubungan jangka panjang yang lebih baik.

\section{Rekomendasi Strategi Pengelolaan Hubungan Dengan Pelanggan Guna Penciptaan Kepuasan dan Loyalitas Pelanggan Business to Business (B2B)}

Berdasarkan hasil wawancara dengan jajaran pimpinan PT. Dinamika Indonusa Prima Cabang Yogyakarta yang diwakili oleh supervisor, dapat dijelaskan sejumlah strategi loyalitas pelanggan (mitra bisnis) yang telah diimplementasikan, sebagai berikut.

\section{Mendanai Program Komunikasi Pema- saran Mitra Bisnis}

Guna mengelola hubungan jangka panjang dengan mitra bisnis, perusahaan secara rutin mendanai dan memfasilitasi kegiatan pemasaran yang dilakukan oleh mitra bisnis. Hal ini dilakukan dengan meng- 
cover seluruh biaya periklanan dan biaya pameran bagi toko-toko yang menjadi mitra bisnis perusahaan. Disamping itu perusahaan juga memberikan fasilitasfasilitas pendukung pemasaran seperti: billboard, sepanduk, brosur dan tools promosi lainnya. Kegiatan-kegiatan tersebut memberikan dampak positif dengan semakin termotivasinya mitra bisnis untuk meningkatkan kinerja penjualannya dan terbangun hubungan yang baik antara perusahaan dengan mitra bisnis.

\section{Merancang Progam Loyalitas Pelanggan}

Program loyalitas pada mitra bisnis selaku pelanggan diberikan oleh perusahaan dalam bentuk Frequency Program yang dirancang untuk memberikan penghargaan kepada pelanggan yang secara kontinyu melakukan pembelian produk dan dalam kuantitas minimal tertentu. Reward yang diberikan perusahaan beragam, seperti: pemberian harga khusus, pemberian kompensasi khusus baik yang berupa financial maupun non financial seperti: wisata ke luar negeri.

\section{Memberikan Layanan Tambahan}

Pemberian layanan tambahan diberikan oleh pihak perusahaan kepada mitra bisnis sebagai layanan penyerta dari penghantaran produk inti. Layanan tambahan yang diberikan antara lain berupa: training product knowledge yang diberikan oleh pihak perusahaan kepada mitra bisnis khusnya bagian penjualan (wiraniaga, SPG). Hal ini ditujukan agar wiraniaga mampu menjelaskan produk dengan baik dan tepat kepada konsumen. Selain pelatihan, perusahaan juga memberikan jasa layanan tambahan yang berupa penataan atau display product di lokasi penjualan mitra bisnis maupun pada saat kegiatan pameran berlangsung.

Mengacu pada strategi yang telah diimplementasikan untuk mengelola hubungan dengan pelanggan pada pemasaran Business to Business (B2B) maka untuk semakin memperkuat terciptanya kepuasan dan loyalitas pelanggan, maka dalam penelitian ini direkomendasikan sejumlah strategi berikut.

1) Membangun Kepercayaan dan Kredibilitas Perusahaan. Upaya membangun kepercayaan perusahaan kepada mitra bisnis dapat dilakukan dengan menunjukan kompetensi dan integritas perusahaan terhadap pelanggannya sehingga akan tercipta hubungan jangka panjang yang sehat. Kredibilitas perusahaan perlu dibangun dan diciptakan karena hal ini mengindikasikan tingkat dimana pelanggan yakin bahwa perusahaan dapat merancang dan mengirimkan produk sesuai dengan kebutuhan dan keinginan pelanggan. Kredibilitas perusahaan dapat dibangun melalui: kepercayaan perusahaan, keahlian perusahaan dan pelayanan perusahaan terhadap pelanggan.

2) Meningkatkan Kualitas Pelayanan Pada Pelanggan. Peningkatan kualitas layanan dapat dilakukan dengan meningkatkan frekuensi layanan kepada pelanggan atau mitra bisnis baik sebelum maupun sesudah transaksi. Kulaitas layanan perlu didukung pula dengan sejumlah aktivitas berikut (Lupiyoadi dan Hamdani, 2006) : menjalankan accountable marketing yakni perusahaan secara kontinyu melakukan checking pada pelanggan untuk mengidentifikasi tingkat kebutuhan pelanggan dan informasi pasar, melakukan reactive marketing yakni perusahaan menyediakan akes yang mencukupi dan mudah dihubungi oleh mitra bisnis, melakukan partnership mareting yakni dengan manjalin kerjasama secara regular dengan mitra bisnis dengan tujuan untuk membantu memperbaiki kinerja mitra bisnis.

3) Meningkatkan Koordinasi Vertikal. Koordinasi vertikal antara perusahaan penyedia produk dengan mitra bisnis perlu ditingkatkan sehingga hubungan aktivitas transaksi bisnis menjadi lebih bernilai bagi kedua belah pihak. Dengan meningkatkan koordinasi vertikal diharapkan dapat: meningkatkan kegiatan 
bisnis yang lebih substansial antar kedua belah pihak, meningkatkan tingkat keuntungan, dan mencegah terjadinya ketidak harmonisan hubungan bisnis antar kedua belah pihak.

4) Mengelola Hubungan Yang Bersifat Kon traktual dan Kolaboratif. Hubungan kontraktual dengan mitra bisnis bersifat lebih jangka panjang sehingga diharapkan mamapu mempertahankan tingkat loyalitas mitra bisnis dan secara langsung akan berpengaruh pada kinerja financial perushaan. Disamping itu perlu dikembangkan hubungan bisnis yang bersifat kolaboratif dimana tercipta hubungan saling membantu bukan hanya dalam hal-hal yang bersifat transaksional.
5) Memanfaatkan Teknologi Informasi dalam Mendukung Aktivitas Pemasaran. Dengan memanfaatkan teknologi informasi maka akan meningkatan efektifitas dan efisiensi dalam aktivitas pemasaran kepada mitra bisnis, sehingga diharapkan dapat meningkatkan kepuasan dan loyalitas pelanggan. Adapun manfaat menggunakan teknolgi informasi dalam pemsaran B2B anatar lain sebagai beikut (Kotler dan Amstrong, 2009): memangkas biaya transaksi baik bagi penyedia produk maupun mitra bisnis, mengurangi waktu antara pemesanan dan pengiriman, menciptakan system pembelian yang lebih efisien, dan membangun hubungan yang lebih personal dengan mitra bisnis.

\section{DAFTAR PUSTAKA}

Adisaputro, G, (2010), Manajemen Pemasaran: Analisis untuk Perancangan Stratgei Pemasaran, Yogyakarta: UPP STIM YKPN.

Budiyuwono, N (2010), Pengantar Statistik Ekonomi dan Perusahaan, Yogyakarta: UPP AMP YKPN

Coviello N.E., R.J. Brodie, P. J. Danaher, W. J. Johnston, (2002), "How Firms Relate to Their Markets: An Empirical Examination of Contemporary Marketing Practices", Journal of Marketing: Vol. 66, No. 3, pp. 33-46.

Griffin, J (2003), Customer Loyalty: How To Earn it, How to Keep it, John Willey and Sons, Inc. Co

Hennkisson, T dan Wall W (2009), How To Create Satisfaction: Customer Satisfaction in B2B Relationship, Thesis: Uppasala University.

Kotler, P. (2009), Marketing Management: Analysis, Planning, Implementation and Control, 12th Edition. Upper Saddle River, New Jersey: Prentice Hall Inc.

Kotler P, dan Keller K (2009), Marketing Management, 13th edition, Pearson education, Inc.

Kotler, P. dan Armstrong, G, (2009), Prinsip-Prinsip Pemasaran, edisi ke 12, PT. Erlangga.

Lam, Y, Shankar, V, Murthy (2004), “Customer Value, Satisfaction, Loyalty and Switching Cost: An Illustration From A B2B Service Context", Journal of The Academy Of Marketing Science, Vol. 32, No. 3

Liao, H (2012), "Service Quality and Customer Satisfaction: Direct and Indirect Effects in a B2B Customer Loyalty Framework", The Journal of Global Business Management, Vol. 8

Lupiyoadi, R. dan Hamdani, A, (2006), Manajemen Pemasaran Jasa, Jakarta: Salemba Empat

Marantika, A (2012), Analisis Tingkat Efektivitas Promosi Terhadap Penjualan Springbed Airland di DIY Tahun 2008 - 2010, Skripsi, Universitas Mercu Buana Yogyakarta, tidak dipublikasikan 
Rauyruen, P, Miller, E, Barrett, J (2007), Relationship Quality as A Predictor Of B2B Customer Loyalty, School Of Marketing, University Technology of Sydney.

Tonton, A. dan Gyamfi,O (2006), Maintaining Customer Relationship in B2B Market, Thesis in Business Administration, Jonkoping International Business School.

Tjiptono, Chandara, Diana (2004), Marketing Scales, Yogyakarta: Andi Offset

Yee, S (2008), Customer Perceived Quality, Relationship Quality and Business Loyalty: An Example of B2B Organization, University of Malaya.

Zeithaml, V.A., Bitner, M.J., (2000), Service Marketing, New York: McGraw-Hill. 